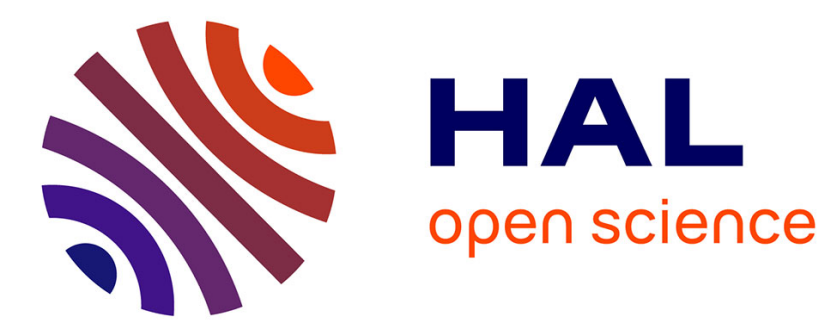

\title{
The Achievement of a Decentralized Water Management Through Stakeholder Participation: An Example from the Drôme River Catchment Area in France (1981-2008)
}

Emeline Comby, Yves-François Le Lay, Hervé Piégay

\section{- To cite this version:}

Emeline Comby, Yves-François Le Lay, Hervé Piégay. The Achievement of a Decentralized Water Management Through Stakeholder Participation: An Example from the Drôme River Catchment Area in France (1981-2008). Environmental Management, 2014, 54, pp.1074 - 1089. 10.1007/s00267014-0378-8 . halshs-01085841

\section{HAL Id: halshs-01085841 \\ https://shs.hal.science/halshs-01085841}

Submitted on 21 Nov 2014

HAL is a multi-disciplinary open access archive for the deposit and dissemination of scientific research documents, whether they are published or not. The documents may come from teaching and research institutions in France or abroad, or from public or private research centers.
L'archive ouverte pluridisciplinaire HAL, est destinée au dépôt et à la diffusion de documents scientifiques de niveau recherche, publiés ou non, émanant des établissements d'enseignement et de recherche français ou étrangers, des laboratoires publics ou privés. 
The Achievement of a Decentralized Water Management Through Stakeholder Participation. An Example from the Drôme River Catchment Area in France (1981-2008)

Emeline Comby, Yves-François Le Lay, Hervé Pigay

\begin{abstract}
Different water Acts (e.g., the European Water Framework Directive) and stakeholders involved in aquatic affairs have promoted integrated river basin management (IRBM) over recent decades. However, few studies have provided feedback on these policies. The aim of the current article is to fill this gap by exploring how local newspapers reflect the implementation of a broad public participation within a catchment of France known for its innovation with regard to this domain. The media coverage of a water management strategy in the Drôme watershed from 1981 to 2008 was investigated using a content analysis and a geographic information system (GIS). We sought to determine what public participation and decentralized decision-making can be in practice. The results showed that this policy was integrated because of its social perspective, the high number of involved stakeholders, the willingness to handle water issues, and the local scale suitable for participation. We emphasized the prominence of the watershed scale guaranteed by the local water authority. This area was also characterized by compromise, arrangements, and power dynamics on a fine scale. We examined the most politically engaged writings regarding water management, which topics each group emphasized, and how the groups agreed and disagreed on issues based on their values and context. The temporal pattern of participation implementation was progressive but worked by fits and starts.
\end{abstract}

\title{
Keywords
}


Local newspapers, Content analysis, Environmental attitudes, Public Participation, Water policy, Stakeholders 


\section{Introduction}

The implementation of the Water Framework Directive (WFD), the current step in European water management, requires that water bodies have a "good ecological and chemical status" by 2015 and a more integrated management strategy (Pollard and Huxham 1998; Hering et al. 2010). This directive affects twenty-eight countries and entails "an important trend toward an ecosystem-based approach for water policy and water resource management" (Kallis and Butler 2001: p. 125). Over the last three decades, major changes have occurred in the way that environments are managed, especially with regard to natural elements such as landscapes, ecological richness, biodiversity, and natural heritage (Bravard et al. 1999). The traditional river-engineering practice has progressively changed into a softer choice for river management (Gilvear 1999). This development is particularly evident given the evolution of French legislation concerning rivers (Piégay et al. 2002). Many European countries have progressively evolved from user objectives regarding regulation and management. In addition, environmental objectives have attempted to reconcile environmental potential with human needs in terms of safety and resource availability within integrated river basin management (IRBM; Molle 2009). Concerning integrated water resource management, the U.S. National Research Council (2013: p. 19) suggests "although there is a vast literature on this subject, there is no single definition of the concept, or commonly idealized model of its implementation. In general, however, it describes a systematic approach to managing water and related environmental resources, which considers natural systems, socioeconomic conditions, and institutions and governance structures". The challenges of IRBM strategies include a social perspective: social learning based on a polycentric governance system for natural resources, the involvement of stakeholders in policy making, and the development of new attitudes to constructively address differences (Pahl-Wostl 2002; Mostert et al. 2007). 
Such policies should be based on a participative approach involving the public (Kaika 2003) because informative questions and debates about the environment at a local level are critical. The environment is one of the major issues within media and cultural studies "since the news media play a crucial role in framing this contested terrain" (Anderson 1997: p. 1).

Historically, the social sciences have investigated the relationship between the media and the environment through hazards and disasters (Committee on Disasters and the Mass Media 1980; Friedman et al. 1987). More recently, scientists have focused on risks (Sandman et al. 1987; Allan et al. 2000). Researchers pay attention to the public's perception of the environment through the media (Burgess 1990; Hansen 1993; Anderson 1997). Scientific interest was found to be two-fold, focusing on public perception and how to communicate to the public (Wakefield and Elliott 2003; Llasat et al. 2009; Bakir 2010).

Newspapers offer a window through which to evaluate the evolution of public perception. They furnish the raw material that explains how the past reality was built (Hayward and Osborne 1973) over more than a century (Gregory and Rowlands 1990; Vuorisalo et al. 2001) without any memory bias. Ibsen and Brunsden (1996) highlighted three temporalities in newspaper research: real time with the production of information in a brief time interval, regular backups and data accumulation, and a record over very long periods. As the relationship between scientists and their field of study is often discontinuous over time, newspapers can compensate for an absence of scientific data. Newspapers give scientists knowledge about what local communities may remember about their environment. Three kinds of press coverage can be established: local, regional and national newspapers. Local newspapers always present, above all, a focus on local and regional situations (Rashid 2011), events (Kitzinger 1999) and communities (Spencer and Triche 1994). Delitala (2005) showed two advantages of local and regional newspapers. First, the journalist described phenomena that occurred near his home and included more personal and precise information. 
In such cases, the journalist might have the same point of view as the local community because he belonged to that community.

Newspapers are a part of readers' daily lives and are one of the elements that can mould the relationship between people and their environment (Waitt 1995), construct public discourses (Boykoff 2007), and shape the public perception of risk (Ferreira 2004). The majority of the public depends on media information (including e-media) because they cannot experience the entire reality. Personal experience, the media and social links (through family, friendship and also school, or the army) are each only one medium of instruction about certain situations. Although newspapers do not typically tell readers what to think (Rogers et al. 1993), they can tell them what to think about. These issues frame readers' thoughts (Loë 1999). No one can evaluate which type of media influences the public the most efficiently because of the complexity and the number of daily media messages (Wahlberg and Sjöberg 2000), but content can construct attitudes while bringing certain problems and points of controversy forward.

The media is only one source of the points of view regarding the environment; this source can be biased, inaccurate, exaggerated, and simplistic. Furthermore, the media is guilty of presenting polarizing arguments (Vasterman et al. 2008) and uses personalization, dramatization, and novelty (Boykoff and Boykoff 2007). The media presents events that concern unusual, unexpected, and emotional threats toward human life and property (Salomone et al. 1990). Journalists select information that sells newspapers and can influence readers' moods (Sood 1987). Newspapers can distort the perception of reality. However, the media also advises citizens to ask politicians and decision-makers to address environmental issues (Pasquarè and Pozotti 2007). Following Boykoff (2011: p. 28), we argue that "the media community serves a vital role in communication process between science, policy and the public." The environment seems to be an issue for citizens and decision-makers "through 
claims-making and communication" (Hansen 2010: p. 8). The media plays a crucial role in the sustenance or contestation of political choices in hazardous situations (Carvalho 2005; Lester 2010). These choices entail political actions such as the writing of laws and provisions that influence water policy and management.

We reviewed newspaper studies to assess the changes in river management while using their coverage to understand the shift in human-river relationships. We explored how the implementation of a decentralized water policy is reflected in local newspapers. The requirements of legislation such as the WFD and the European Aarhus Convention (1998) raise a need for including "the public" in planning and decision-making (Maynard 2013). This strategy is a choice to construct and manage river basin water resources with regard to their quality and quantity using a participatory approach (Jaspers 2003). The current political trend within natural resource management shows an increase in "collaborative management arrangements" to deal "with the benefits of deliberative learning processes, increasing the legitimacy of decision making, as well as with the need to adapt systems of resource management to more spatially and temporally functional scales" (Matti and Sandström 2011: p. 385). This water management is related to a complex river systems approach, polycentric governance, a cross-sector analysis, and shared information at a decentralized scale (PahlWostl 2007). We investigated the different points emphasized by Molle (2009) using a crosssectional approach to account for the complexity of local problems including the diversity of stakeholders, positive or negative human uses, decentralization, public participation, and local scale processes. The integration allows more participants to be involved (through the local democracy) and more topics to be considered to attempt to satisfy all stakeholders. The following questions are addressed: (i) How did environmental aspects and different interests increase the frequency, and scope of the water topics discussed and progressively widen the set of participants? Furthermore, (ii) how did the need for water management reveal 
the degree to which different groups agree with regard to various issues, considering political, social, and economic values and spatial integration, and the need to cooperate in a coherent "natural" area (i.e., a catchment) despite the dichotomy between upstream and downstream reaches? Finally, (iii) are integrated policies based on linear and continuous participatory decision-making processes as long as involved stakeholders are willing to find and share solutions when critical events occur?

To explore this evolution, we investigated the Drôme River in France from 1981 to 2008. Because of this twenty-eight year archive, we were able to process temporal events (e.g., floods) and long-term water management trends. In 1981, the Drôme catchment area underwent a new integrative policy, and a participative local water government has been involved since 1994. Although European and French river management uses the Drôme River management strategy as a model, many crises have occurred in this basin, which continually undergoes severe damage.

\section{The Drôme Basin: An Example of an Innovative Water Policy over the Last Three}

\section{Decades}

The advocacy coalition framework (ACF) developed by Sabatier (1998) insists on the requirement of a time perspective of at least a decade to understand the process of policy change and to get a valuable assessment of policy impacts. The implementation of a broad participation can be considered as a policy subsystem which consists of a variety of stakeholders who are concerned with a problem (i.e., water management) and who want to influence public policy. This policy involves value priorities, perceptions of current problems and causal relationships, and the efficacy of various policy instruments (Sabatier 1998) (e.g., 
the implementation of public participation). The policy subsystem involves both a functional (e.g., a broad participation) and a territorial dimension (Albright 2011), in this case, the Drôme catchment.

Draining a region of the Southern French Alps, the Drôme River is a tributary of the Rhône River characterized by an active bedload transport and locally well-preserved braided reaches (figure 1). The Drôme River drainage area is $1,640 \mathrm{~km}^{2}$, which includes 83 municipalities and 40,000 inhabitants. The population density shows spatial contrasts (figure 1). The highest densities are in Livron, Loriol, Allex, Crest, and Aouste-sur-Sye. This basin is part of a rural area, although its proximity to the Rhône valley entails urbanization and higher densities in the downstream reach. This river is a significant economic resource because of agriculture and tourism (Landon et al. 1998). Its management involves the development of a subMediterranean climatic area marked by occasional but intense rainfall in spring and autumn, two-month-long droughts in the summer, and an alpine area with snowmelt (Piégay et al. 2004). The major problems of the Drôme River include river incision due to gravel mining, changes in land use (specifically, the increase of forested land), and the construction of "bank protection, levees and other embankments" (Kondolf et al. 2002: p. 41). This incision entailed the destruction of two bridges during floods in 1994 and 2003, and expensive engineering projects were needed to restore the levees built in the $19^{\text {th }}$ century. The Drôme River is one of the last natural rivers of its size in France because dams do not prevent its water from normal hydrological functioning.

In the 1980s, this river was too polluted for swimming (Bethemont 2001). Owing to a groundbreaking governance system called Syndicat Mixte de la Rivière Drôme abbreviated SMRD - a local structure for participative water governance located in Saillans in the Middle Drôme- that began in 1981 in collaboration with local governments, the stakeholders became pioneers in developing a participatory approach with the CR (see acronyms in figure 2). This 
CR was a contract between the public authorities and local inhabitants that aimed to restore water quality, mitigate flood risk via maintenance practices, and pay for operations and actions (e.g., river maintenance) in different parts of the watershed. This basin was the first French catchment that had a watershed-scale program (Schéma d'aménagement et de gestion des eaux abbreviated to SAGE) owing to the creation of a decentralized government for water (Commission locale de l'eau in a shortened form CLE). "This opportunity to bring together different stakeholders with conflicting views to debate these problems collectively gave hope that a common agreement could be reached" (Pont et al. 2009: p. 362-363). The CLE assembled elected people from local institutions (50\% of members, for example mayors), different types of users (25\% of its members included homeowners, environmentalist NGO members, farmers, anglers, canoeists, hotel keepers, and so on), and regional or national institutions (25\% of its members include regional and national water agencies, the national forest agency, and so on) to create SAGE and implement the program. This repartition of members must respect the regions of the catchment: downstream and upstream reaches, urban and rural parts, valleys and mountains. Following the French water law of 1992, the SAGE assumed power in 1997 and favored a comprehensive, integrated, and sustainable water management system that was implemented from 1997 to 2008.

Local scales and management frameworks (notably, the participation, partnership, and coordination of objectives and measures) are currently used as a model for WFD. During the 8th International River Symposium in Brisbane, Australia, the Drôme River project won the 2005 International Thiess Riverprize for its restoration, protection, and management efforts. This catchment area applied a national policy concerning fish as well as water quality and quantity, a regional policy concerning the entire Rhône watershed (SDAGE, a regional SAGE produced by the Rhône-Mediterranean water agency; figure 1), and a local policy concerning two participatory organizations: the SMRD and CLE (figure 2). However, 2008 marked the 
end of the first SAGE and the second CR. A new CLE was created to continue the first policy from 1981 to 2008 . This article uses twenty-eight years of data to highlight the results of this water policy.

Following Sabatier (1998), the ACF may present a general overview of our case study: relatively stable parameters correspond to biophysical characteristics, distribution of resources, and economic structures and social values. These parameters constrain the policy subsystem, which is composed of different coalitions (i.e., various actors who share a set of beliefs and try to co-operate). Another set of factors (called external events) can change over the course of a decade and influence the subsystem: changes in public opinion regarding river management priorities and changes in French (water) policy, which favor a decentralized government.

\section{Material and Methods}

The Newspaper Sample: A Catchment Approach

The principal dataset addresses the water policies and themes covered in Le Crestois and Le Journal du Diois. Because a fifth of the Drôme watershed population pays to read these newspapers, a significant audience knows and recognizes this information. Both of these weeklies have the same editorial line (i.e., to report local information), the same audience (approximately 4,000 newspapers are sold each week, despite the low number of inhabitants in this catchment), similar prices (approximately 1.50 euros), and the same structure (i.e., front pages, editorials, local and regional pages, readers' letters, classified advertisements, and advertising). They print their own items. Neither local newspaper shows political preferences. 
They are some of the only sources of information regarding water management in the watershed. Le Crestois, which is published in Crest, focuses on the downstream reach, whereas Le Journal du Diois, which is published in Die, focuses on the upstream reach (figure 1). The comparative analysis of two newspapers helps to strengthen data, evaluate the variability of opinions and debates, and assess the biases of these sources.

One of the major problems affecting local newspapers is their absence of Internet databases (Driedger 2007). Consequently, to obtain local news coverage, scientists must use archives, which imply a longer investment of time than Internet databases. The archives of the Drôme Department, located in Valence (Rhône-Alpes, figure 1), receive and archive all published weeklies. Their historical collections are open to the public and can be freely consulted. As newspapers can be used to retrospectively evaluate public perceptions of environmental issues, the raw material for the study was collected from January $1^{\text {st }}, 1981$ to December $31^{\text {st }}$, 2008.

We thoroughly read all weekly newspapers to select articles regarding water management in the Drôme catchment. Each article reviewed for our research was photographed and numerically archived. A database was compiled using each article, and each article was characterized using the following variables: publication date, page, authors, and actors (anglers, canoeists, environmentalists, experts, farmers, journalists, hunters, organization members, politicians, quarrymen, riverside residents, tourists, and other users).

\section{Content Analysis}

Berelson (1952: p. 18) defined content analysis as "a research technique for the objective, systematic, and quantitative description of manifest communication." This technique focuses on communication as a reflection of public perception according to newspaper content 
(McKay and Finlayson 1982). This method includes qualitative data in a quantitative form (Hayward and Osborne 1973). After reading each article, categories were created to gather the information from each item (Boholm 2009). This standard method enables scientists to compare different texts (Mayring 2000).

Article codes were assigned after reading each article (Wakefield and Elliot 2003; Brossard et al. 2004); these codes corresponded to all angles regarding the river as an interface between environmental and human aspects. We aimed to determine relationships between reports (table 1), wishes (table 2), and actions (table 3). One person coded all articles to avoid intercoder variability and completed a table. We also reproduced the classification scheme for item tone to question the potential success following Loë (1999), thereby distinguishing different coverage. These tones included mostly positive information regarding water management, mostly negative information regarding water management, peripheral information not directly related to water management, neutral information (i.e., facts), and balanced information (i.e., the same number of positive and negative comments).

Because of this quantitative approach toward the texts, we used a multiple correspondence analysis (MCA) to describe the trends of all of the articles in a descriptive perspective, and to explore the relationships among different variables in an explanatory perspective (Lebart et al. 1984) using the ade4 package (Thioulouse et al. 1997) for R (Ihaka and Gentleman 1996). The factorial map describes and sums the structure of cloud synthesizing modalities, variables, and the numerous contingency tables constructed from tables 1,2 , and 3 . This twodimensional representation is synthetic and shows the proximity between modalities and variables owing to the creation of factorial axes. An overlap witnesses a proximity of coordinates on a factor for two variables and so the emergence of some common themes in the same context. Because the IRBM used a cross-sector approach, we sought to determine how many themes were addressed and whether they were combined. We then displayed the 
years on the first three axes to determine which year corresponded with which themes to develop temporal patterns. We also used the Shannon index (H') to indicate stakeholder diversity using the actors mentioned by the articles' authors. Because participation is a key aspect, we posited that high scores reveal a more efficient agora-that is to say a central place for political debate and social life. Finally, a GIS was created to establish the geography of public perception because the watershed scale seems to be crucial for such a policy. For each article, the places mentioned were recorded on different scales (e.g., municipalities and river reaches) to compare the differences between the downstream and upstream reaches and to show discontinuities in newsworthiness.

\section{Results}

To answer our three questions, we first introduced the temporal pattern of the dataset. We then explored its spatial patterns by comparing the two newspapers. Finally, we synoptically explored how stakeholders are involved and how topics are discussed over time.

Water Management Reports from 1981 to 2008

Figure 3 shows the distribution of articles that covered water management in the Drôme catchment. Water management was addressed in 1,103 articles, including 653 from Le Crestois (downstream) and 450 from Le Journal du Diois (upstream). On average, Le Crestois produced 23.3 water management articles per year, while Le Journal du Diois published 16.6 articles per year. 
If these newspaper publication patterns are similar (e.g., the peaks in 1989 and 2005 and the low interest in water management in the early 1980s), they also differ. The peak in 1997 was only true of Le Crestois. If 1989 produced a peak in both weeklies, the patterns over time are different: Le Crestois showed a progressive increase, whereas Le Journal du Diois displayed an abrupt rise.

Spatial Contrasts in These Reports

Le Crestois most frequently covered the following river reaches (in order): the Basse Drôme, the Gervanne and the Ramières, the Bourne, the Drôme Moyenne, and the Granette (figure 4). Conversely, Le Journal du Diois most frequently covered the Haute Drôme and the Drôme Moyenne.

Le Crestois covered more municipalities than Le Journal du Diois (figure 4). Le Crestois most frequently covered Crest and the Ramières, whereas Le Journal du Diois most frequently covered Saillans and Die. Several municipalities were mentioned with regard to dispersion logic, such as archipelagic geography. The logic that Le Journal du Diois used was random and scattered, whereas the municipalities covered in Le Crestois were concentrated.

The Evolution of the Topics Covered in the Two Newspapers Concerning River Management

A MCA performed on the content analysis summarized the topics discussed as shown by the correlation score (figure 5a). On the positive coordinates, the two first axes illustrate hydrological risk issues (e.g., droughts and floods). The third axis focuses on water quality and conservation (figure $5 b$ ). 
After studying these three major factors, we focused on certain variables. The positive coordinates of the F1 axis were related to the low quantity of water, the mention of farmers and membership organizations, water resources, and risk management for the lack of water (figure 6). The negative coordinates of $\mathrm{F} 1$ were related to floods, erosion banks, landslides due to high flows, maintenance, and problems due to the channel's state (e.g., vegetation encroachment and wood jam formation). The second axis opposed two sets of actors communicating with regard to different stakes. The negative coordinates highlight environmentalists, hunters, and tourists with regard to river management, river preservation, and ecological restoration (e.g., the protected braided reach, Les Ramières). The positive coordinates, which concerned quarrymen and riverside residents, were focused on excess water, channel risk or healthiness, channel geomorphology through incision and aggradation, crossing difficulties, floods, bank erosion, and river maintenance.

To study temporal patterns, we displayed the years on the factors to determine which years are best represented by the axes defined by figure 5. Le Crestois discussed peak drought interests from 1986 to 1990 and from 2003 to 2008 (positive coordinates of F1 axis, figure 6a), whereas Le Journal du Diois paid significant attention to this subject in 1981, 1982, 1989, 1990, 1991, and 2003. Le Crestois discussed floods and bank erosions from 1981 to 1984 and from 2002 to 2007; Le Journal du Diois discussed these effects from 1982 to 1986 as well as in 1991, 1994, 1995, and from 2001 to 2008 (positive coordinates of F2 axis, figure 6b). Le Crestois primarily discussed river environment conservation and restoration in the 1990s, whereas Le Journal du Diois discussed these issues in the 1980s and at the end of the 1990s (negative coordinates of $\mathrm{F} 2$ axis, figure $6 \mathrm{c}$ ).

\section{Stakeholder Participation}


Table 4 shows that half of the articles were written by journalists; however, many other stakeholders used the media to provide their opinions. Different types of stakeholders were identified (figure 7), including river users and politicians as the primary agents. Politicians communicated more than users in Le Crestois in 1997, whereas the reverse was true in 2003 and 2005. Users were the most frequently mentioned stakeholders in Le Journal du Diois in 1989; a drought and the Bez dam project occurred during this year. The next most significant stakeholders included riverside residents, farmers, and anglers; the third group of actors was composed of experts, canoeists, and tourists. Secondary stakeholders differed slightly between the newspapers: Le Crestois mentioned quarrymen and farmers more often than Le Journal du Diois.

Figure 8 highlights the diversity of the authors in the two newspapers over time. The widest diversity of authors wrote in Le Crestois from 1986 to 1994 and from 2005 to 2008. The widest diversity wrote in Le Journal du Diois from 1984 to 1992 and from 2004 to 2008. Significantly less author diversity was present from 1995 to 1999 for both newspapers. Figure 9 focuses on the viewpoints adopted in each article with regard to river issues. The most common points of view were positive in both newspapers, with maximum frequencies of 0.75 in 1996 and 0.75 in 1998 for Le Crestois and Le Journal du Diois, respectively. Positive coverage regularly increased during the late 1990s. Since 1996, the majority of articles has often been positive. Negative coverage did not show a linear trajectory due to specific peaks in 1982 and from 1989 to 1994, from 2002 to 2003, and from 2005 to 2006 in Le Crestois and from 1989 to 1991, from 1994 to 1995, and in 2003 in Le Journal du Diois. Balanced coverage showed the same pattern over time in both newspapers, with great importance provided from 1983 to 1992 and from 2004 to 2008. 


\section{Discussion}

\section{Achieving Participation through Stakeholder Diversity}

The first question (i) assumed the existence of a diversity of stakeholders and issues involved in river management. Efficient governance combines identified institutions at (inter)national scales and actor networks in a local policy arena (Pahl-Wostl 2007). Many actors have written in newspapers to provide their opinions. The stakeholders involved in writing a water management strategy can be classified into many groups, and these groups exemplify a type of participation. Users and riverside residents are part of the group of major actors who engage in a real dialogue during water meetings. Two classic types of stakeholders are also closely related to this political choice: farmers because of irrigation and anglers because of fish and their habitats. The CLE discusses economic interests with farmers, quarrymen, canoeists, and tourists as well as ecological issues with anglers, experts, and environmentalists. This governance has real power because it is composed of politicians, whose decisions carry weight.

Nevertheless, difficulties led to a debate that facilitated the creation of a genuine integrated strategy to regulate these difficulties. For example, water quality was a problem in 1987 when a departmental edict did not allow people to swim in the Drôme River. "We imagined our beautiful river under the cleansing sun and its rays [...]. But a departmental act forbids people from swimming during the summer. Did the sun collector crash?” (04/27/1987, Le Journal du Diois). Local stakeholders felt betrayed by the pollution because they thought, "the thin wedge of water, the flow between the gravel and the sun exposure naturally cleans up the Drôme River water" (07/27/1983, Le Journal du Diois). Since the creation of the first watertreatment plant at Saillans in 1992, the number of these plants has increased. In the 2000s, 
water quality has improved to correspond to a good ecological status (as the European WFD expected).

The Drôme basin water policy was the result of the participation of many stakeholders, despite the environmental requirements of a sub-Mediterranean area and the different points of view concerning the river. The newspapers emphasized the role of local policies, which seemed to be the most appropriate scale for certain socio-environmental regulations (Gibbs and Jonas 2000). The Drôme River is often considered to be a good example of an integrated strategy because it gathers each type of stakeholder to plan new actions that favor the hydrosystem and considers all of its dimensions.

\section{Questioning Integration at the Watershed Scale}

To answer the second question (ii), a single management strategy (applied at the watershed scale) generates difficulty reconciling the various issues with several local communities. Local concerns affect upstream areas differently from downstream areas and can weaken the choice of a unique watershed regulation. Other dichotomies (including valleys/mountains or urban/rural areas) can be problematic with regard to applying a water policy because the water uses might differ.

The local press can enlighten readers about hazardous places while emphasizing drought and flood frequency. Risk assessment was one of the reasons driving the creation of new watershed provisions. River reaches with a significant amount of media coverage are often related to hydrological extremes such as a lack of water resources (Bez, Gervanne and Bourne) and floods (Roanne, Grenette and Meyrosse). Temporal ruptures are structured by local socio-environmental crises that influence the local political agenda (e.g., the droughts in 1989, 1990, and 1991 or the floods in 1993, 1994, and 1995). We focused on highly 
publicized water shortage events to evaluate the shifts in the upstream and downstream community relationships and their power dynamics. In 1989, the Drôme River was completely dry in its lower reach. In May 1989, a dam construction project was planned to maintain the Drôme River flow from 1991 to 1993. A NGO called "Save the Bez valley" was created in the upstream reach. The members were against this project because "the downstream reach farmers must only accept the Drôme natural supply" (09/08/1989, Le Journal du Diois). In the upstream reach, the dam would have inundated mountainous riverscapes, which might have caused problems for recreation and tourism. This conflict revealed the difficulties between the upstream and downstream reaches with regard to sharing resources. The inhabitants of the upstream reach did not want to lose their landscapes, live with a dam or within a reservoir drawdown zone (with low water in the summer), or accept the agricultural choices of downstream farmers (i.e., irrigated crops in a sub-Mediterranean area). The Bez dam was not constructed because of this disagreement. This failed project has been a catalyst to understand the necessity of having a local government that represents the entire watershed. After the droughts in 1989, 1990, and 1991, the Drôme catchment was chosen as a test site to apply SAGE in France for the first time to begin a new approach toward water policy.

The CLE is a place for debate that does not homogenize the different preferences concerning water use which can be seen as "basic attributes of the problem area and distribution of natural resources" and as different "sociocultural values" which are part of "relatively stable parameters" (Weible et al. 2011: p. 352). To illustrate current upstream/downstream differences in the interests of stakeholders, we compared two newspaper headlines on May $27^{\text {th }}, 2007$, reporting the end of the first CLE and the beginning of the second. The journalists of Le Crestois focused on the human and river managers, whereas those of Le Journal du Diois focused on the river. Although the topic was the same, the choice of photographs and 
the words used to present the change were not. Specifically, the pictures in Le Crestois focused on politicians and users, whereas those in Le Journal du Diois showed the stream in a gorge near a large gravel bar. The inhabitants of the most urbanized reach were shown speaking out about the Drôme River, whereas the most rural reach was shown as a natural and mountainous landscape without humans. These two points of view might have been a source of tension preventing the implementation of an integrated catchment management system. The location of the SMRD in the Middle Drôme can be seen as a useful spatial compromise, although the upstream reach might have strongly influenced the municipality of Saillans. The results showed that the places that were well covered by the media were characterized by high population densities. The two cities where the newspaper firms are based (Crest and Die) are well represented. Many local issues attract the attention of newspapers due to their geographic proximity (Kenix 2005). Llasat et al. (2007) showed that events in urban areas receive greater coverage than those in rural areas; however, the Drôme basin showed a different pattern. Its two major cities (Livron and Loriol, which represent a third of the catchment population) were not the most-mentioned places. These cities might be more influenced by the Rhône River than the Drôme River. The municipality of Saillans has only 1,000 inhabitants and received significant media coverage from the two newspapers because of its central location.

If a river management system seems to be desirable at the catchment scale, then public perception refers to a more local scale (e.g., municipalities or river reaches). Although onefourth of the articles concerned the catchment scale, one of the major obstacles was related to the diversity of the spatial contexts that entail different interests and power dynamics. We emphasize the degree to which the stakeholders disagreed on a few questions because of their values or spatial contexts. However, these tensions did not seem to weaken the need to share water resources at the catchment scale. 
Tackling the Temporal Logic of Implementing a Stakeholder Participation

According to the third question (iii), public participation should be implemented through a continuous progression to consider numerous topics, points of view, and issues. But this linear model is linked with relatively stable parameters without considering events. Albright (2011: p. 487) suggests: "by drawing attention to a policy problem, focusing events may illuminate policy failures that need to be addressed, encourage a new understanding of a policy problem, or promote the formation of new policy alternatives or the reconsideration of policies". Local attitudes toward the crises and hazards in the Drôme watershed were a more important factor with regard to local water management choices than global awareness and environmental concerns such as sustainable development. The words used in these articles did not refer to many global issues (e.g., climate change or sustainable development), which confirms the results of Bush et al. (2002). Certain discourses peaked at different times in relation to issues and the critical decisions made to address local emergencies related to water quantity and quality. When this integrative management system was considered a progressive policy, crises sped up certain decision-making processes. The adaptation and participation of local stakeholders might be one of the major assets of integrative management when emergencies or crises occur. Converting a typical top-down water policy into a bottom-up water governance system means adopting ways of behaving and thinking that must be more interactive and flexible to satisfy potential needs.

Although certain agents do not always attend the CLE meetings, they are invited and have the potential to be represented. The Drôme basin newspapers can represent this local forum and the participative approach associated with collective engagement by mentioning the various stakeholders from different areas of the catchment during CLE meetings. This multi- 
participant management system efficiently created the first SAGE program. Nevertheless, the debates regarding topical issues did not end after the first SAGE program concluded. One of the major problems of the SAGE was the implementation of a document that did not change during its lifetime. If the CLE is a flexible and participatory organization, then the SAGE should be considered a rigidly written program. Stakeholders continued to be involved in the CLE meetings to create the new SAGE from 2008 to 2013. This investment highlights the sustainability of this management strategy. Local stakeholders tried to find a balance among the various issues, sites, attitudes, and attempts to regulate tensions. Although a true consensus was not reached, many compromises made this management system possible; however, it took five years to construct the second SAGE and its new official document. Local public issues might undermine or accelerate the implementation of participation. At the catchment scale, we argue that newspapers illustrate temporal changes (e.g., at the end of the 1980s) that likely correspond to IRBM strategies. This implementation is progressive but works by fits and starts. We notice the superposition of two temporal patterns: a linear implementation that was sped up by emergencies such as droughts, floods, or poor water quality.

\section{Conclusions}

Water management is a newsworthy topic in the Drôme watershed. Our study showed that newspapers could help to analyze water management strategies. This type of water policy is integrative considering the number of stakeholders and their willingness to address water issues at the catchment scale together. Certain criteria were successful, whereas others were more complicated to apply because of non-shared values or interests and the logic of power. 
Efficient water governance systems should be based on the quality of the partnerships created among various stakeholders at different scales. Different stakeholders are part of the water policy addressed in the current paper, which might explain its efficiency. Nevertheless, these stakeholders do not agree on certain priorities or forms of regulation. Public participation is based on compromises, which can be weakened by tensions or conflicts. Local attitudes toward crises and hazards in the Drôme watershed seemed to determine local water management more so than global environmental concerns such as sustainable development. Politicians seemed to make major decisions during emergencies. River management systems are feasible at the catchment scale, whereas public perception refers to a more local scale (e.g., municipalities or river reaches). The Drôme river management continues to be an innovative example at the national scale. In 2013, a new stage of its water policy was implemented with a second SAGE and a new CR.

We suggest that newspapers present more than a vision; they are also stakeholders that need to be analyzed in the same way as all local stakeholders. Local newspapers are not just a gobetween; they are local community stakeholders that help to define how the environment is perceived and should be perceived in the future. They can relay new policies and build new relationships between local populations and the environment. Local newspapers can disseminate information to contribute to environmental education. Newspapers are not neutral, and stakeholders might be able to use this fact. The media, particularly newspapers, can play an important role in favoring contemporary environmental changes (O'Donnell and Rice 2008). In 2005, previous researchers used the two newspapers studied herein to communicate scientific results and inform people about the geomorphological, ecological, and socioeconomic issues related to the Drôme River within the framework of a European LIFE program. 


\section{Acknowledgments}

This research project has been supported by the ZABR (Zone Atelier Bassin du Rhône) and a program of French National Research Agency (Agence Nationale de la Recherche - ANR) called GESTRANS (GEStion des risques liés aux crues par une meilleure prise en compte du TRANSit sédimentaire, ANR-09-RISK-004) and a Ministry program (Créateurs de Drôme, "Eaux et Territoires"). We thank the editor and the three anonymous reviewers whose suggestions greatly improved the quality of the manuscript. 


\section{References}

Albright E A (2011) Policy Change and Learning in Response to Extreme Flood Events in Hungary: An Advocacy Coalition Approach. The Policy Studies Journal 39(3):485-511 Allan S, Adam B, Carter C (2000) Environmental Risks and the Media. Routledge, London Anderson A (1997) Media, culture and the environment. University College London Press, London

Bakir V (2010) Media and risk: old and new research direction. Journal of Risk Research 13(1):5-18

Berelson B (1952) Content Analysis in Communication Research. The Free Press

Bethemont J (2001) Ressources en eau et territoires hydrauliques. Revue de l'Economie méridionale 49(194-195):123-132.

Boholm M (2009) Risk and Casualty in Newspaper Reporting. Risk Analysis 29(11):15661577

Boykoff M T (2007) Flogging a dead norm? Newspaper coverage of anthropogenic climate change in the United States and United Kingdom from 2003 to 2006. Area 39(4):470-481 Boykoff M T, Boykoff J M (2007) Climate change and journalistic norms: A case-study of US mass-media coverage. Geoforum 38:1190-1204.

Boykoff M. T. (2011) Who Speaks for the Climate. Making Sense of Media Reporting on Climate Change. University Press Cambridge, Cambridge

Bravard J-P, Landon N, Peiry J-L, Piégay H (1999) Principles of engineering geomorphology for managing channel erosion and bedload transport, examples from French rivers. Geomorphology 31:291-311 
Brossard D, Shanahan J, McComas K (2004) Are Issue-Cycles Culturally Constructed? A comparison of French and American Coverage of Global Climate Change. Mass Communication and Society 7(3):356-377

Burgess J (1990) The Production and Consumption of Environmental Meanings in the Mass Media: A research Agenda for the 1990s. Transactions of the Institute of British Geographers 15(2):139-161

Bush J, Moffat S, Dunn C E (2002) Contextualisation of Local and Global Environmental Issues in North-east England: implications for debates on globalisation and the 'risk society'. Local Environment 7(2):119-133

Carvalho A (2005) Representing the politics of the greenhouse effect. Critical discourse studies $2: 1-29$

Committee on Disasters and the Mass Media (1980) Disasters and the Mass Media. National Academy of Sciences, Washington

Delitala A M S (2005) Perception of intense precipitation Events by Public Opinion. Natural Hazards and Earth System Sciences 5:499-503

Driedger S M (2007) Risk and the Media: A comparison of Print and Television News Stories of a Canadian Drinking Water Risk Event. Risk Analysis 27(3):775-786

Ferreira C (2004) Risk transparency and cover up: media narratives and cultural resonance. Journal of Risk Research 7(2):199-211

Friedman S M, Gorney C M, Egolf B P (1987) Reporting on Radiation: A Content Analysis of Chernobyl Coverage. Journal of Communication 37(3):58-67

Gibbs D, Jonas A E G (2000) Governance and regulation in local environmental policy: the utility of a regime approach. Geoforum 31:299-313

Gilvear DJ (1999) Fluvial geomorphology and river engineering: future roles utilizing a fluvial hydrosystems framework. Geomorphology 31:229-245 
Gregory K, Rowlands H (1990) Have global hazards increased? Geography review 4(2):35-38

Hansen A (1993) The Mass Media and Environmental Issues. Leicester University Press, Leicester

Hansen A (2010) Environment, media and communication. Routledge, London Hayward R, Osborne BS (1973) The British Colonist and the Immigration to Toronto of 1847: a Content Analysis Approach to Newspaper Research in Historical Geography. Canadian Geographer 17(4):391-402

Hering D, Borja A, Carstensen J, Carvalho L, Elliott M, Feld CK, Heiskanen A-S, Johnson RK, Moe J, Pont D, Lyche Solheim A, van de Bund W (2010) The European Water Framework Directive at the age of 10: A critical review of the achievements with recommendations for the future. Science of the Total Environment 408:4007-4019 Ibsen M-L, Brunsden D (1996) The nature, use and problems of historical archives for the temporal occurrence of landslides with specific reference to south coast of Britain, Isle of Wight. Geomorphology 15:241-258

Ihaka R, Gentleman R (1996) R: a language for data analysis and graphics. Journal of Computational and Graphical Statistics 5:299-314

Jaspers GWJ (2003) Institutional arrangements for integrated river basin management. Water Policy 5:77-97

Kaika M (2003) The Water Framework Directive: a new directive for a changing social, political and economic. European framework European Planning Studies 11(3):299-316 Kallis G, Butler D (2001) The EU water framework directive: measures and implications. Water Policy 3(2):125-142

Kenix LJ (2005) A Comparison of Environmental Pollution Coverage in the Mainstream African American, and other Alternative Press. The Howard Journal of Communications 16(1):49-70 
Kitzinger J (1999) Researching risk and the media Health. Risk \& Society 1(1):55-69

Kondolf M G, Piégay H, Landon N (2002) Channel response to increased and decreased bedload supply from land-use change: contrasts between catchments in the Rocky Mountains of Idaho and the Pre-Alps of France. Geomorphology 45:35-51

Landon N, Piégay H, Bravard J-P (1998) The Drôme river incision (France): from assessment to management. Landscape and Urban Planning 43:119-131

Lebart L, Morineau A, Warwick K M (1984) Multivariate descriptive statistical analysis. Wiley, New York

Lester L (2010) Media \& Environment. Conflicts, Politics and the News. Polity, Cambridge Llasat M C, Llasat-Botija M, Barnolas M, Lopez L, Altava-Ortiz V (2009) An analysis of the evolution of hydrometeorological extremes in newspapers: the case of Catalonia, 1982-2006.

Natural Hazards and Earth System Sciences 9:1201-1212

Llasat-Botija M, Llasat MC, Lopez L (2007) Natural Hazards and the press in the western Mediterranean region. Advances in Geoscience 12:81-85

Loë R C (de) (1999) Dam the News: Newspapers and the Oldman River Dam project in Alberta. Journal of Environmental Management 55:219-237

Maynard C M (2013) How public participation in river management improvements is affected by scale. Area 45: 230-238

Mayring P (2000) Qualitative Content Analysis. Forum Qualitative Sozioalforschung / Forum: Qualitative social Research 1(2) 10 p.

Matti S, Sandström A (2011) The Rationale Determining Advocacy Coalitions: Examining Coordination Networks and Corresponding Beliefs. The Policy Studies Journal 39(3):385-410 McKay J M, Finlayson B (1982) Observations on mass media reporting and individual motivation to obtain a flood inundation map - River Torrens, Adelaide, South Australia. Applied Geography 2:143-153 
Molle F (2009) River-basin planning and management: The social life of a concept.

Geoforum 40:484-494

Mostert E, Pahl-Wostl C, Rees Y, Searle B, Tàbara D, Tippett J (2007) Social learning in European river-basin management: barriers and fostering mechanisms from 10 river basins. Ecology and Society 12 http://www.ecologyandsociety.org/vol12/iss1/art19/

National Research Council (2013) Delta Waters: Research to Support Integrated Water and Environment Management in the Lower Mississippi River. The National Academies Press, Washington DC

O’Donnell C, Rice RE (2008) Coverage of environmental events in US and UK newspapers: frequency, hazard, specificity, and placement. International Journal of Environmental Studies 65(5):637-654

Pahl-Wostl C (2002) Participative and stakeholder-based policy design, evaluation and modeling processes. Integrated Assessment 3:3-14

Pahl-Wostl C (2007) Transitions towards adaptive management of water facing climate and global change. Water Resources Management 21:49-62

Pasquarè F, Pozzetti M (2007) Geological hazards, disasters and the media: The Italian case study. Quaternary International 173-174:166-171

Piégay H, Dupont P, Faby J A (2002) Questions of water resources management: feedback of the French implemented plans SAGE and SDAGE (1992-1999). Water Policy 4(3):239-262. Piégay H, Walling D E, Landon N, He Q, Liébault F, Petiot R (2004) Contemporary changes in sediment yeld in an alpine montane basin due to afforestation (the upper Drôme in France). Catena 55:183-212

Pont D, Piégay H, Farinetti A, Allain S, Landon N, Liébault F, Dumont B, Richard-Mazet A (2009) Conceptual framework and interdisciplinary approach for the sustainable management 
of gravel-bed rivers: The case of the Drôme River basin (S.E. France). Aquatic Sciences 71: $356-370$

Pollard P, Huxham M (1998) The European water framework directive: A new era in the management of aquatic ecosystem health. Aquatic Conservation: Marine and Freshwater Ecosystems 8:773-792

Rashid H (2011) Interpreting flood disasters and flood hazard perceptions from newspaper discourse: Tale of two floods in the Red River valley, Manitoba, Canada. Applied Geography 31(1):35-45

Rogers E M, Dearing J W, Bergman D (1993) The Anatomy of Agenda-setting Research. Journal of Communication 43(2):68-84

Sabatier P A (1998) The advocacy coalition framework: revisions and relevance for Europe. Journal of European Public Policy 5(1): 98-130

Salomone K L, Greenberg M R, Sandman P M, Sachsman D B (1990) A Question of Quality: How Journalists and News Sources Evaluate Coverage of Environmental Risk. Journal of Communication 40(4):117-130

Sandman P M, Sachsman D B, Greenberg M R, Gochfeld M (1987) Environmental Risk and the Press: an explanatory assessment. Transaction Books, New Brunswick Spencer J W, Triche E (1994) Media Construction of Risk and Safety: Differential framings of Hazard Events. Sociological Inquiry 64(2):199-213

Sood R, Stockdale G, Rogers E M (1987) How the News Media Operate in Natural Disasters. Journal of Communication 37(3):27-41

Thioulouse J, Chessel D, Dolédec S, Olivier J-M (1997) ADE-4: a multivariate analysis and graphical display software. Statistics and Computing 7(1):75-83

Vasterman P, Scholten O, Ruigrok NA (2008) A model for evaluating risk reporting: The case of UMTS and fine particles. European Journal of Communication 23(3):319-341 
Vuorisalo T, Lahtinen R, Laaksonen H (2001) Urban biodiversity in local newspapers: a historical perspective. Biodiversity and Conservation 10:1739-1756

Waitt G (1995) Media Representation of Forestry and Soil Issues in the Australian Press, 1990-1. Australian Geographical studies 33(2):299-307.

Wahlberg A, Sjöberg L (2000) Risk perception and the media. Journal of Risk Research $3(1): 31-50$

Wakefield SEL, Elliott SJ (2003) Constructing the News: The Role of Local Newspapers in Environmental Risk Communication. The Professional Geographer 55(2):216-226

Weible C M, Sabatier P A, Jenkins-Smith H C, Nohrstedt D, Henry A D, deLeon P (2011) A Quarter Century of the Advocacy Coalition Framework: An Introduction to the Special Issue. The Policy Studies Journal 39(3):349-360 


\section{Figure captions}

Figure 1. The Drôme catchment and its local newspaper coverage: a) the organization of Drôme watershed with tributaries of the Drôme River, circulation of the two main weekly newspapers (Le Crestois and Le Journal du Diois), and population density, and b) the location of the Drôme catchment in France and the area of Rhône regional water agency and SDAGE. Figure 2. A temporal pattern of river integrated management in the Drôme basin and the emergence of polycentric governance from 1981 to 2008: a) Laws and provisions at different scales, and b) Acronyms, the full French name, and a description of these provisions.

Figure 3. Distribution of articles about river issues from 1981 to 2008 in each studied journals $(n=1,103)$.

Figure 4. Quoted river reaches and municipalities in each article and in each newspaper $(n=1,103)$ showing the spatial gaps between the two media coverages. As each newspaper has different numbers of articles, the calculations were based on percentage. The set of articles excludes the articles focused on the Drôme basin as a whole: this set corresponds to $27 \%$ of articles in Le Crestois and 26\% in Le Journal du Diois.

Figure 5. Multiple component analysis (MCA) performed on the content analysis information a) from tables 1, 2 and 3 and the choice of three factors (due to high eigenvalues), a synthesis of topics which seem to be handled together through high correlation score, b) a summary table of high correlation scores to describe the main information of each chosen factor (F1, F2 and F3).

Figure 6. Detailed representation of MCA: a) extracts of the factorial map (F1 X F2) of the MCA performed on the content analysis database: even though the results are part of the same MCA, we scatter these variables on different maps (each map shows one of the studied 
variables and its modalities, when the ellipses sum up $66 \%$ of modalities), b) the temporal pattern of the axes 1,2 and 3 of MCA shows the evolution of the three main topics considering a year scale.

Figure 7. Cumulative occurrence of primary and secondary stakeholders in water management through the two local newspapers between 1981 and 2008. In each article $(n=1,103)$, the main evoked stakeholders were filled in the database. We distinguished two major and secondary stakeholders in each newspaper.

Figure 8. Temporal evolution of the diversity of stakeholders involved in the public debate. The diversity index $\mathrm{H}^{\prime}$ is based on the stakeholder frequency as author of articles and as mentioned stakeholders in newspapers. The higher this score is, the greater the diversity of stakeholders is.

Figure 9. Temporal variations in points of view expressed by articles focused on the river stakes. 
Figure 1. The Drôme catchment and its local newspaper coverage: a) the organization of

Drôme watershed with tributaries of the Drôme River, circulation of the two main weekly newspapers (Le Crestois and Le Journal du Diois), and population density, and b) the location of the Drôme catchment in France and the area of Rhône regional water agency and SDAGE.

a)

The first French Water resources development and management plan

Rhône regional SDAGE area
Drôme catchment: SAGE area
different river sections
The institutional scale

The institutional scale

$\mathrm{Fi}^{3}$ each municipality

Two weeklies

DIE the newspaper office location

IIIIIIIIII the Crestois inner limits of media coverage

11. The Journal du Diois inner limits of media coverage

Population density (population per $\mathrm{km}^{2}$ )

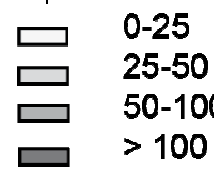

$0-25$

$50-100$

$>100$

Le Crestois

Sources of information : BD CARTHAGEQ, (9) IGN Paris 2008 BD GEOFLA®, @ IGN Paris 2008 Joumalist interviews
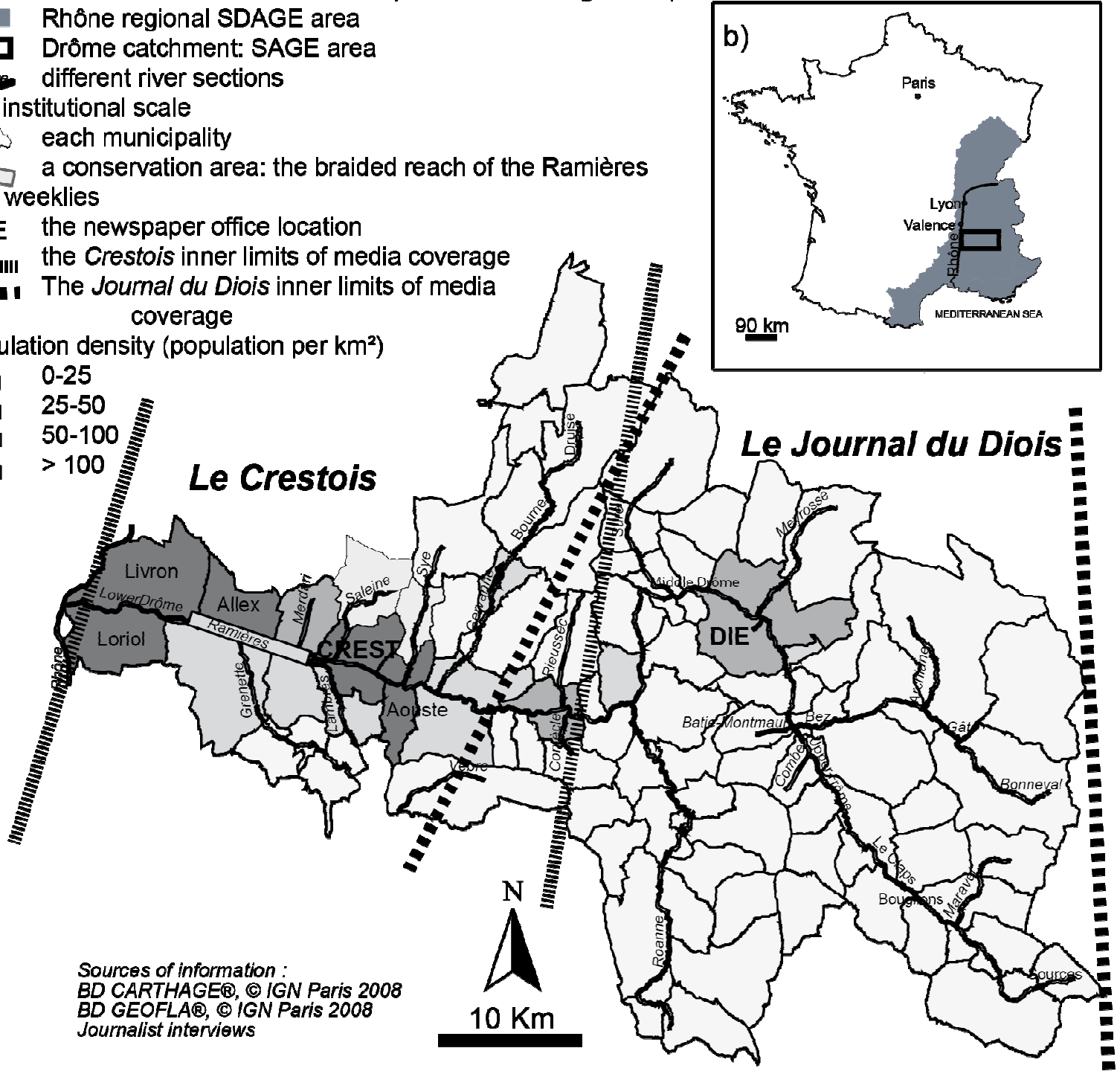
Figure 2. A temporal pattern of river integrated management in the Drôme basin and the emergence of polycentric governance from 1981 to 2008: a) Laws and provisions at different scales, and b) Acronyms, the full French name, and a description of these provisions.

a)

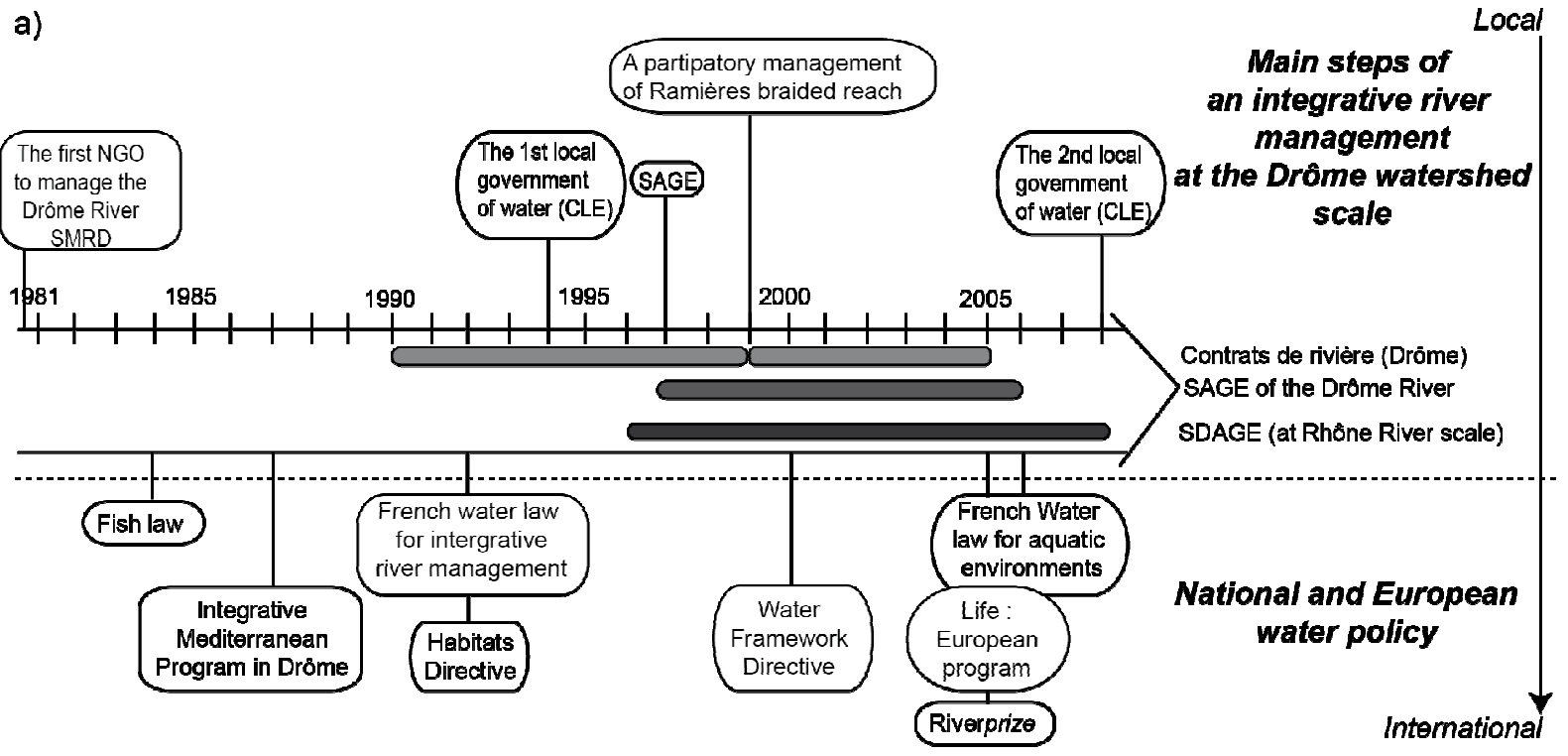

b)

\begin{tabular}{|c|c|c|c|}
\hline Acronym & French word & Translation & Description \\
\hline SMRD & $\begin{array}{l}\text { Syndicat Mixte de la Rivière } \\
\text { de la rivière Dróme } \\
\text { Contrat de Riviere }\end{array}$ & $\begin{array}{l}\text { The Drôme River joint } \\
\quad \text { association } \\
\text { River Contract }\end{array}$ & $\begin{array}{l}\text { A structure responsible for the maintenance of the Drôme River and } \\
\text { the water management and policy in the Drôme River catchment } \\
\text { A technical and economic contract between catchment stakeholders } \\
\text { to restore the river and to mitigate floods }\end{array}$ \\
\hline CLE & Commission locale de l'eau & Local Water Commission & A local government which creates and applies the SAGE \\
\hline $\begin{array}{l}\text { SAGE } \\
\text { SDAGE }\end{array}$ & $\begin{array}{l}\text { Schéma d'aménagement et } \\
\text { de gestion des eaux } \\
\text { Schéma directeur } \\
\text { d'aménagement et de gestion }\end{array}$ & $\begin{array}{l}\text { Water Plannnig and } \\
\text { Management Program } \\
\text { Regional Water Planning and } \\
\text { Management Program }\end{array}$ & $\begin{array}{l}\text { A program at a watershed scale to achieve different objectives and } \\
\text { uses and to protect water resources (quantity and quality) } \\
\text { A program led by a regional water agency with objectives, } \\
\text { measurements and evaluations }\end{array}$ \\
\hline
\end{tabular}


Figure 3. Distribution of articles about river issues from 1981 to 2008 in each studied journals $(n=1,103)$.

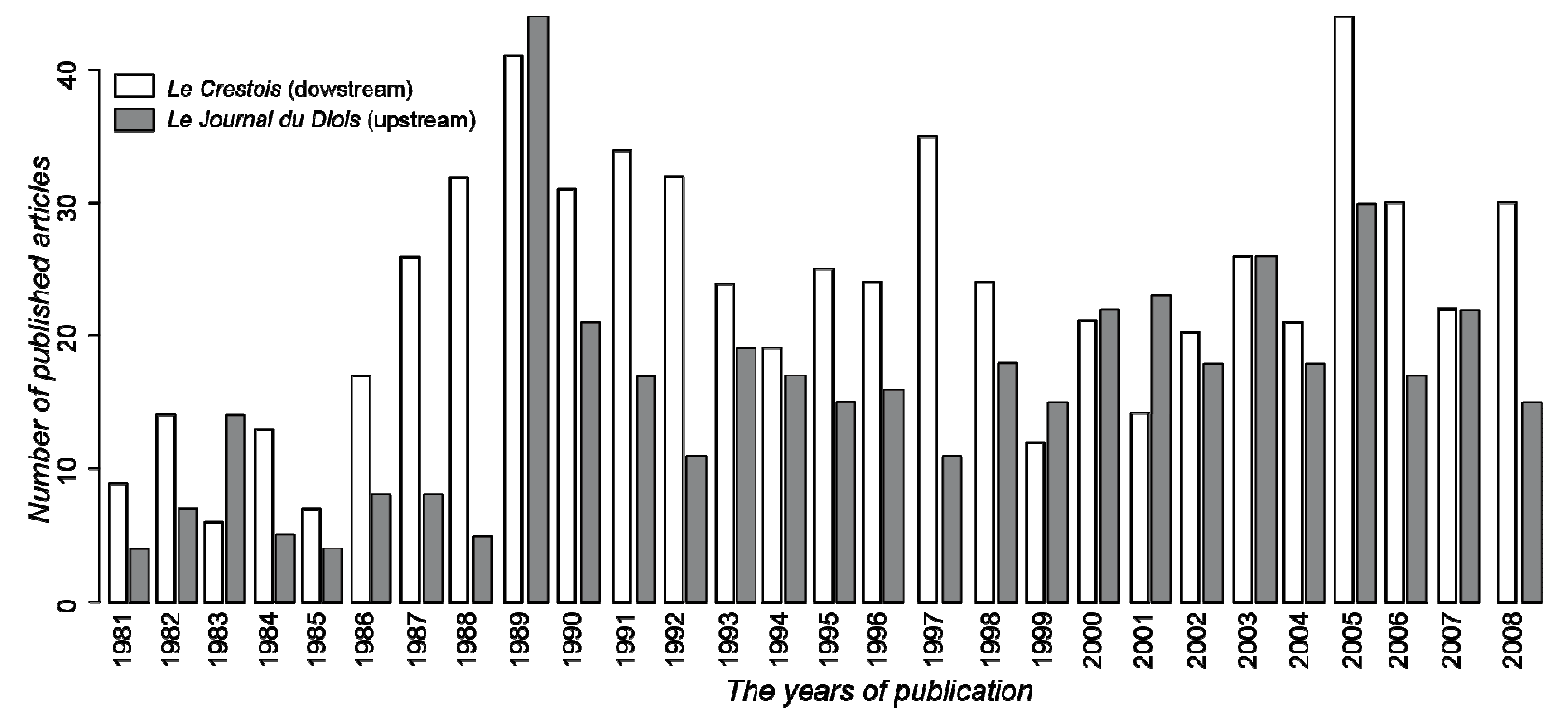


Figure 4. Quoted river reaches and municipalities in each article and in each newspaper $(\mathrm{n}=1,103)$ showing the spatial gaps between the two media coverages. As each newspaper has different numbers of articles, the calculations were based on percentage. The set of articles excludes the articles focused on the Drôme basin as a whole: this set corresponds to $27 \%$ of articles in Le Crestois and 26\% in Le Journal du Diois.

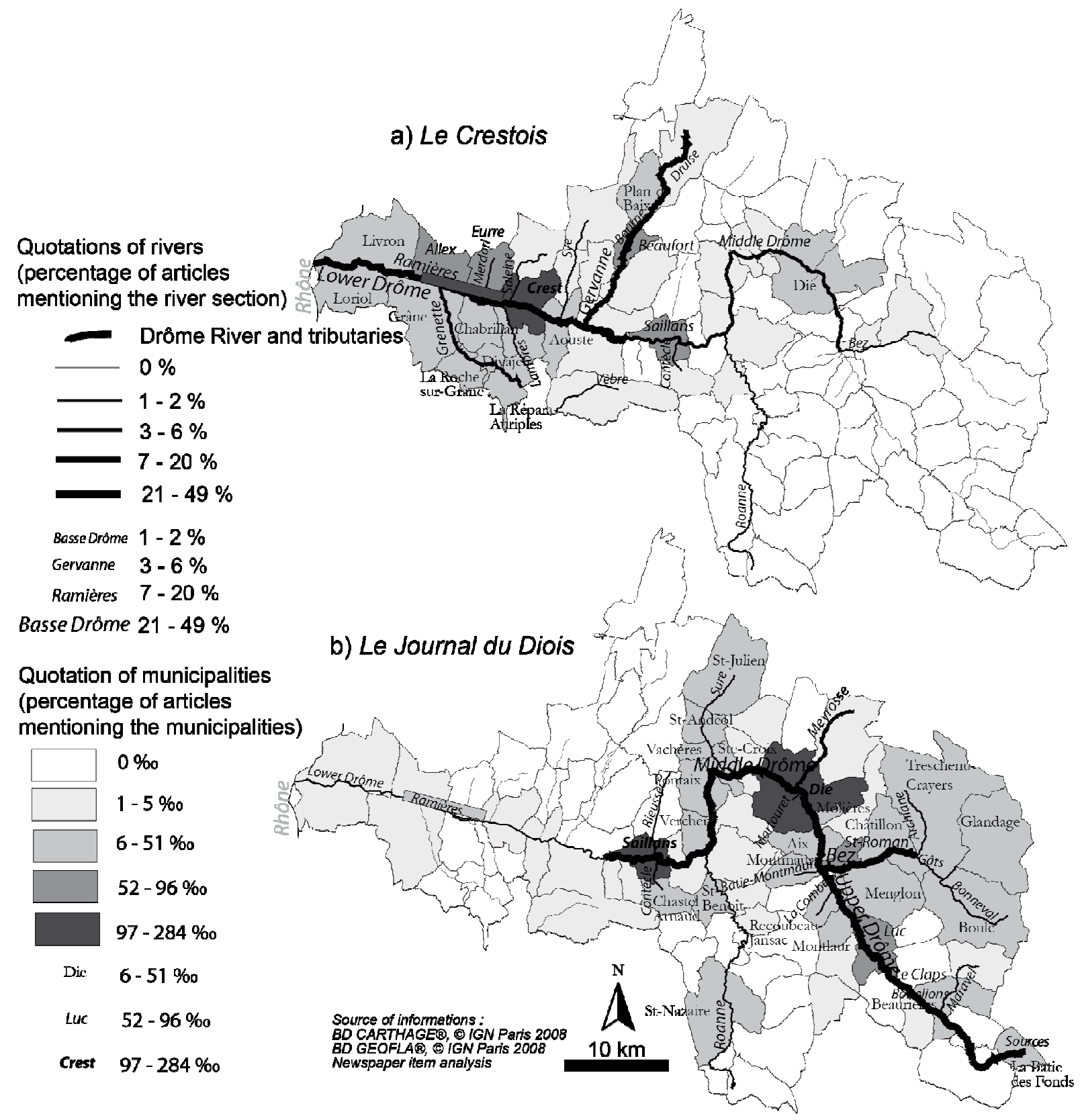


Figure 5. Multiple component analysis (MCA) performed on the content analysis information a) from tables 1, 2 and 3 and the choice of three factors (due to high eigenvalues), a synthesis of topics which seem to be handled together through high correlation score, b) a summary table of high correlation scores to describe the main information of each chosen factor (F1, F2 and F3).
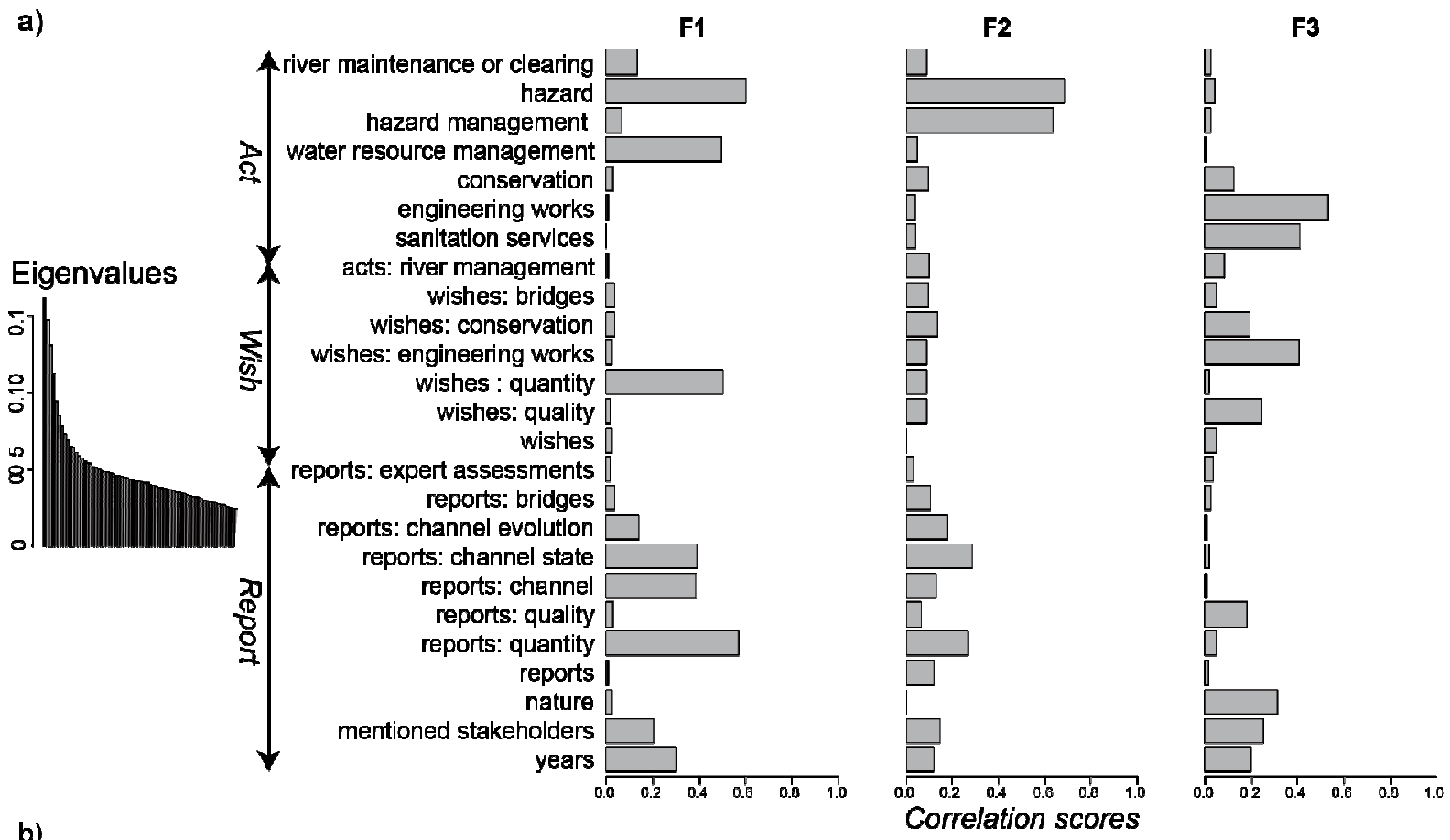

b)

\begin{tabular}{|c|c|c|c|}
\hline & F1 (positive coordinates) & F2 (positive coordinates) & F3 (positive coordinates) \\
\hline Report & $\begin{array}{l}\text { Shortage of water } \\
\text { No report of the channel state } \\
\text { Stakeholders: farmers, NGO } \\
\text { members }\end{array}$ & $\begin{array}{l}\text { Incised or aggraded channel } \\
\text { Bad-maintenance channel } \\
\text { Too much water } \\
\text { Stakeholders: quarrymen, } \\
\text { riverside inhabitants }\end{array}$ & \begin{tabular}{|l} 
Bad quality of water \\
Planned nature or \\
nature-object \\
Stakeholders: scientists, \\
tourists, ecologists
\end{tabular} \\
\hline Wish & More quantity & $\begin{array}{l}\text { Less quantity } \\
\text { More engineering works } \\
\text { More bridges }\end{array}$ & $\begin{array}{l}\text { Sanitation services } \\
\text { Engineering works }\end{array}$ \\
\hline Act & $\begin{array}{l}\text { Hazard management } \\
\text { Hazard: water shortage } \\
\text { Water resource management }\end{array}$ & $\begin{array}{l}\text { Hazard management } \\
\text { Hazard: floods, landslide } \\
\text { No conservation } \\
\text { River maintenance or cleaning }\end{array}$ & $\begin{array}{l}\text { More bridges } \\
\text { More quality } \\
\text { More conservation }\end{array}$ \\
\hline Synthese & Lack of water and droughts & Floods and bank erosion & Conservation and quality \\
\hline
\end{tabular}


Figure 6. Detailed representation of MCA: a) extracts of the factorial map (F1 X F2) of the MCA performed on the content analysis database: even though the results are part of the same MCA, we scatter these variables on different maps (each map shows one of the studied variables and its modalities, when the ellipses sum up $66 \%$ of modalities), b) the temporal pattern of the axes 1, 2 and 3 of MCA shows the evolution of the three main topics considering a year scale.

a)

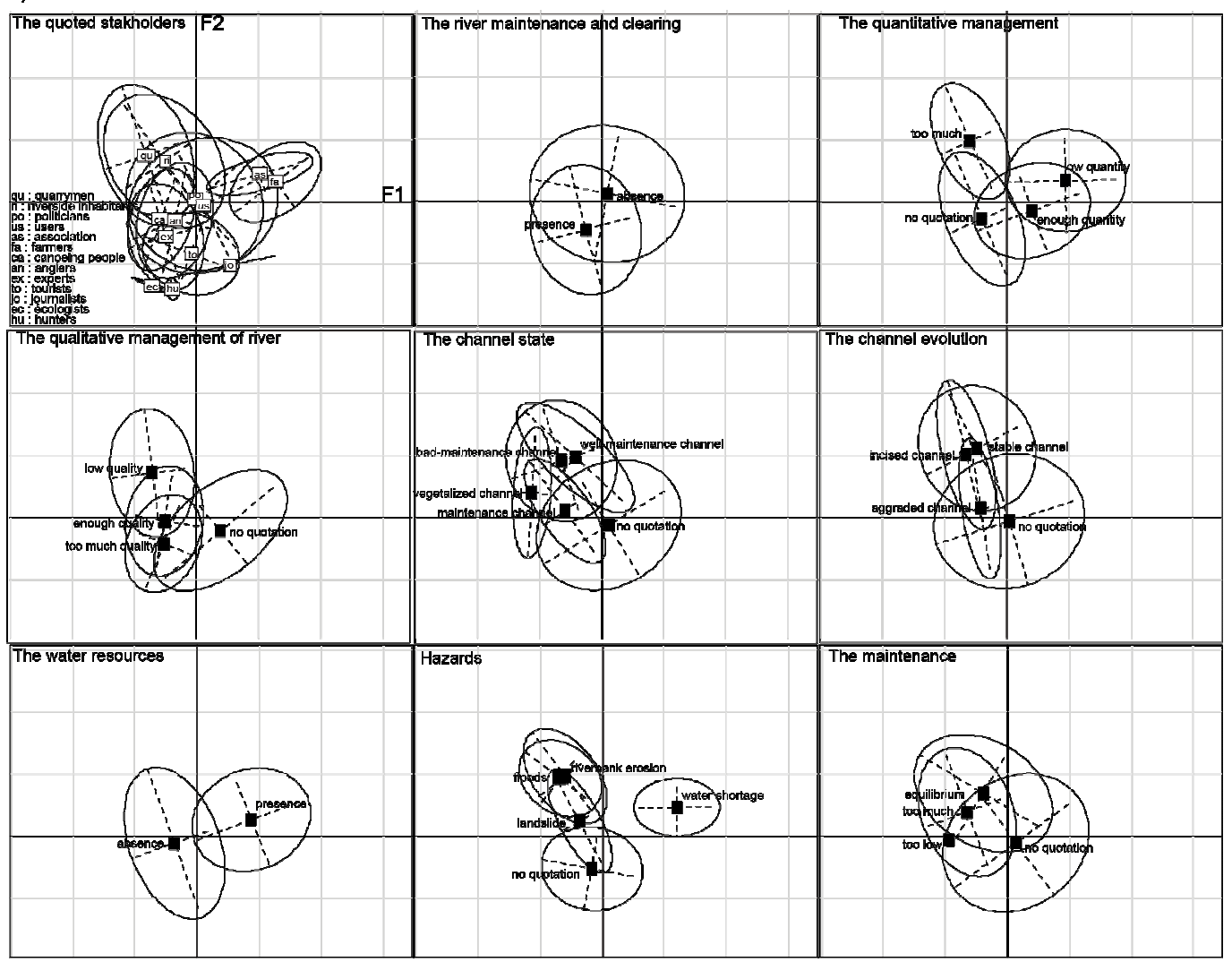

b)

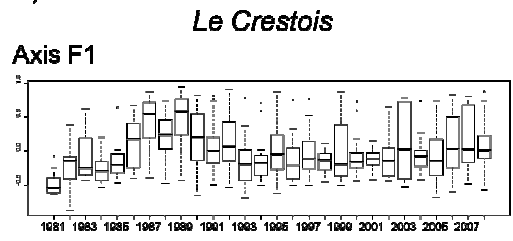

Le Joumal du Diois

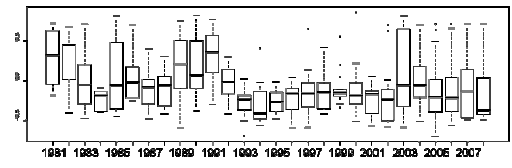

Axis F2
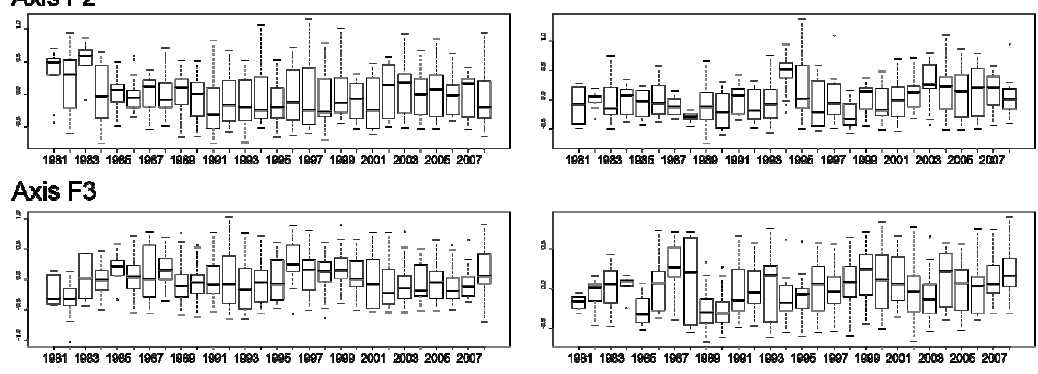
Figure 7. Cumulative occurrence of primary and secondary stakeholders in water management through the two local newspapers between 1981 and 2008. In each article $(n=1,103)$, the main evoked stakeholders were filled in the database. We distinguished two major and secondary stakeholders in each newspaper.
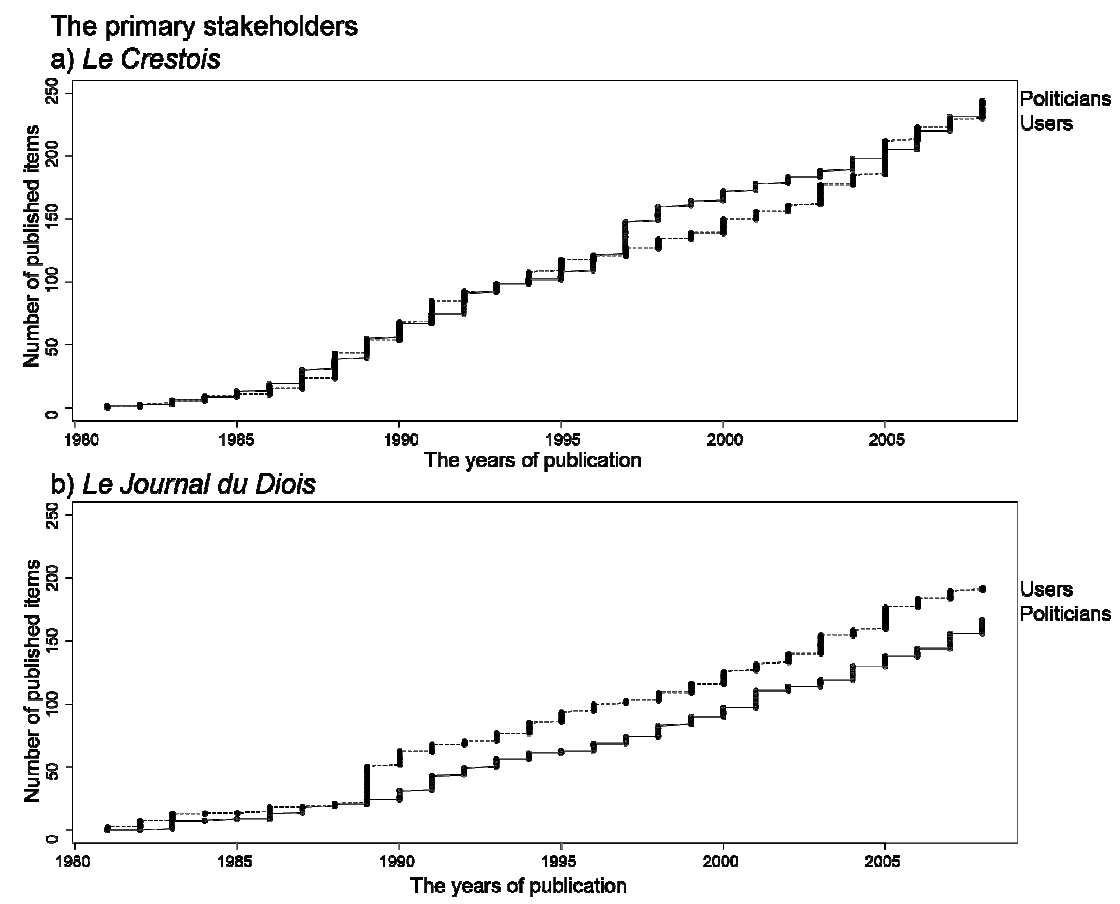

The secondary stakeholders

a) Le Crestois

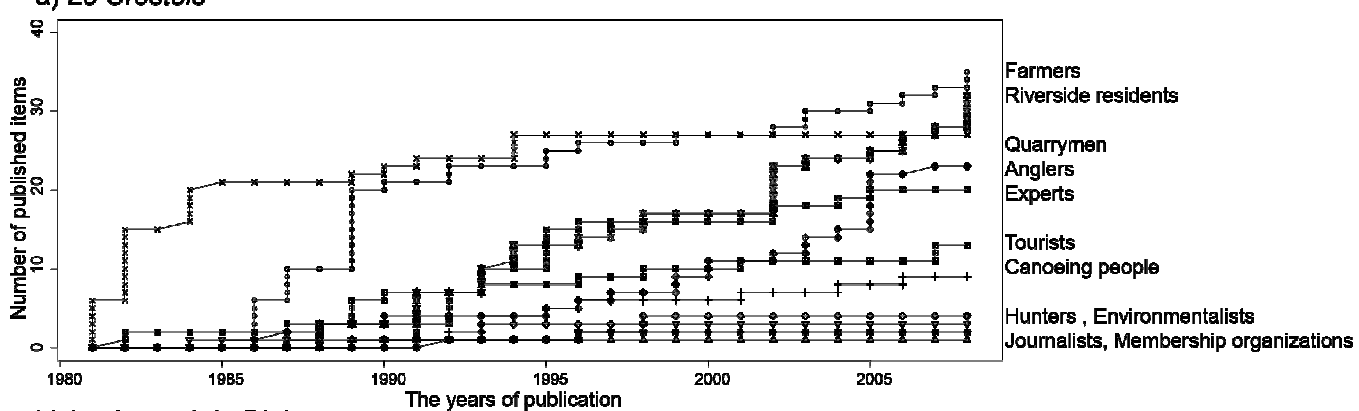

b) Le Journal du Diois

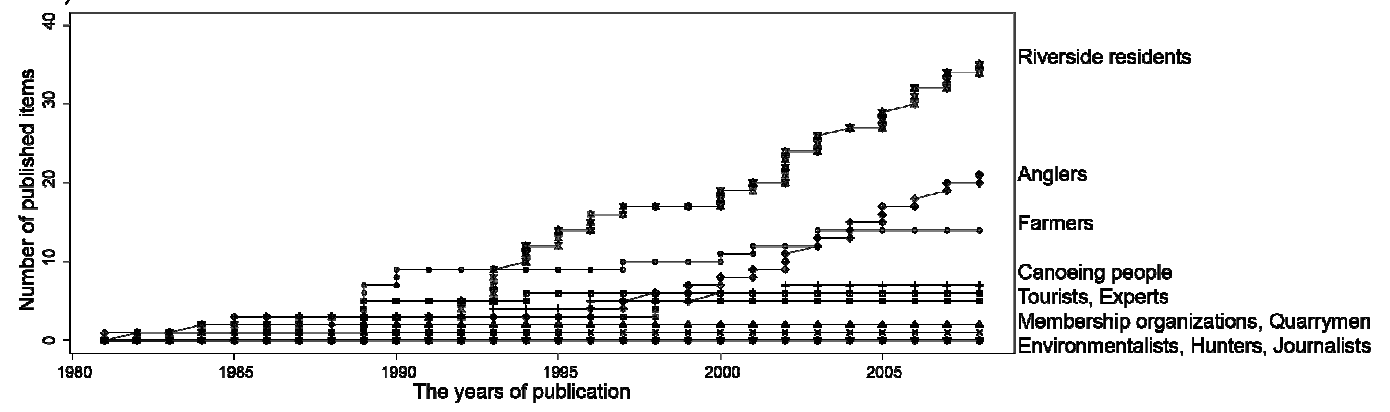


Figure 8. Temporal evolution of the diversity of stakeholders involved in the public debate. The diversity index $\mathrm{H}^{\prime}$ is based on the stakeholder frequency as author of articles and as mentioned stakeholders in newspapers. The higher this score is, the greater the diversity of stakeholders is.

a) Le Crestois

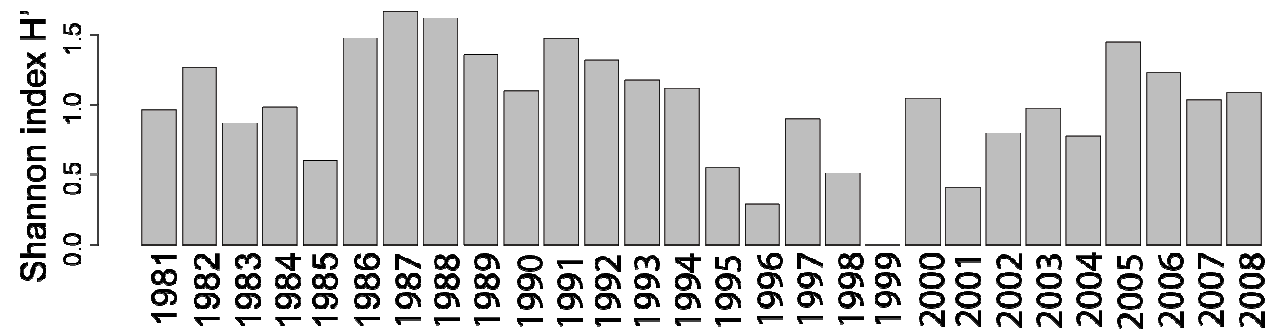

ì b) Le Journal du Diois

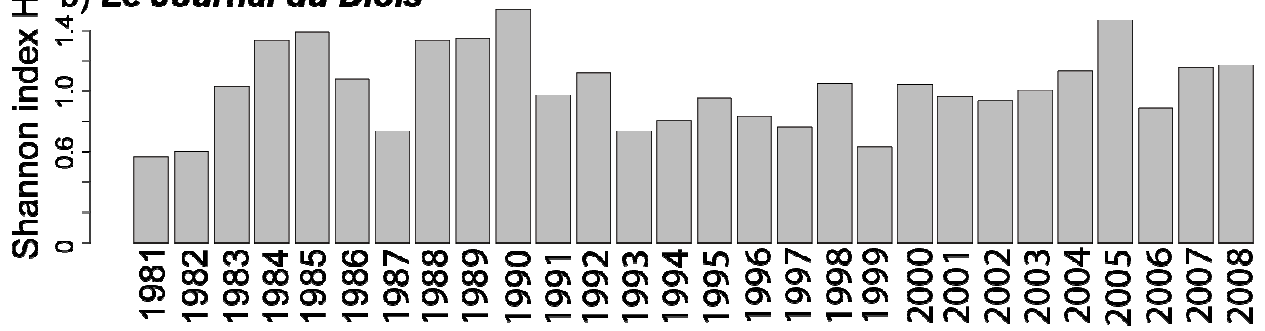


Figure 9. Temporal variations in points of view expressed by articles focused on the river stakes.
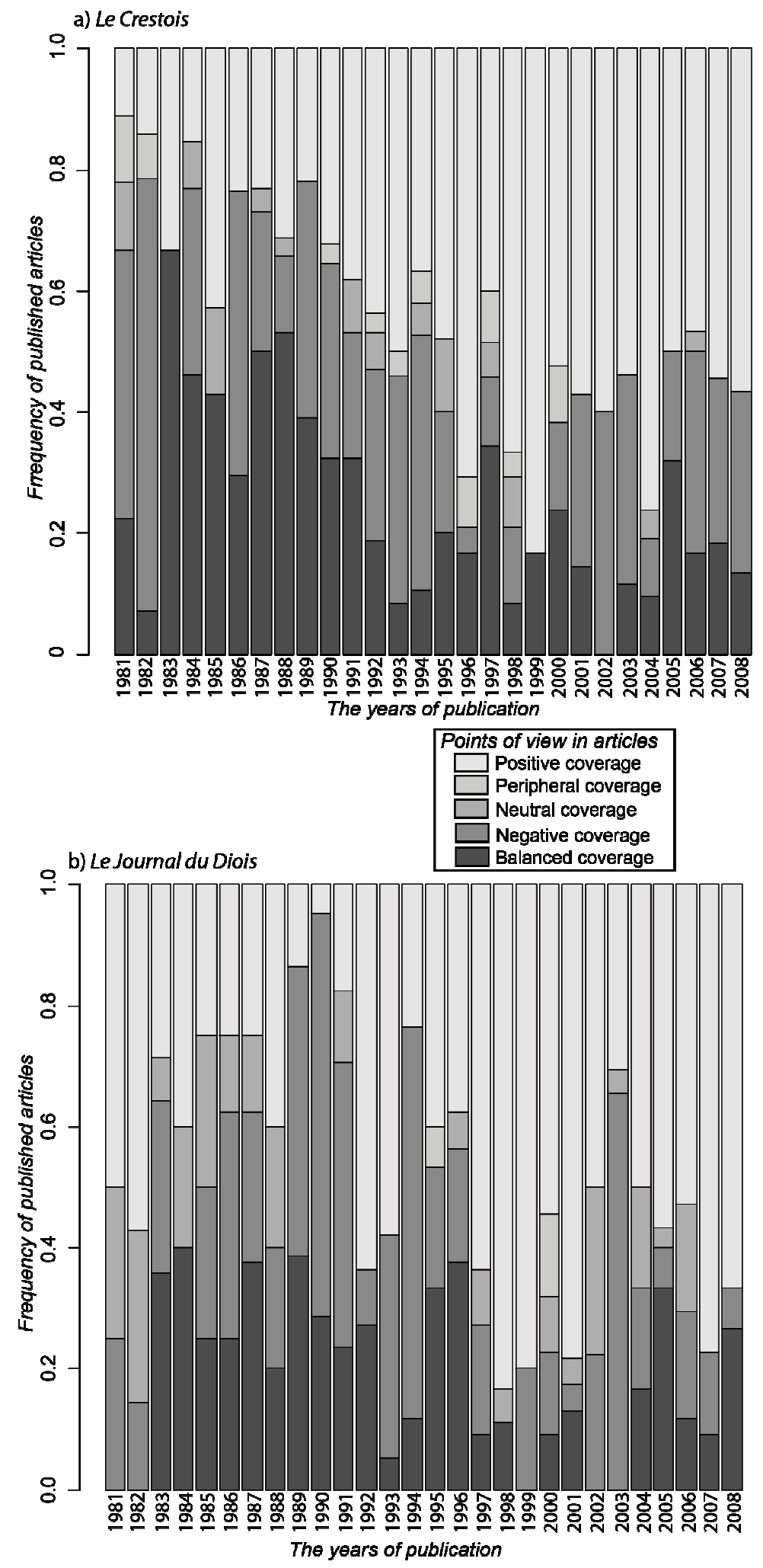


\section{Table captions}

Table 1 . The report codes in newspaper items.

Table 2. The wish codes in newspaper items.

Table 3 . The action codes in newspaper items.

Table 4. The comparison of different authors in the newspapers. 
Table 1. The report codes in newspaper items.

\begin{tabular}{|l|l}
\hline Variables & Codes \\
\hline Evoked observations & Absence / Presence \\
\hline Quality & No quotation / Lack / Medium / Good \\
\hline Quantity & No quotation / Lack / Enough / Too much \\
\hline Expert assessments & No quotation / Lack / Enough / Too many \\
\hline Bridges & No quotation / Difficult / Adequate / Good \\
\hline Channel & No quotation / Presence \\
\hline Channel state & Bad-maintenance channel / Enough / Well-maintenance \\
& channel / Vegetalized \\
\hline Channel evolution & Incised / Stable / Aggraded \\
\hline Nature & Wild nature / Planned nature / Nature-object \\
\hline Evoked stakeholders & Anglers / Associations / Canoeing People / Ecologists / \\
& Experts / Farmers / Hunters / Journalists / Politicians / \\
\hline
\end{tabular}


Table 2. The wish codes in newspaper items.

\begin{tabular}{|l|l}
\hline Variables & Codes \\
\hline Expressed wishes & Absence / Presence \\
\hline Quality & No quotation / Less / Same / Better \\
\hline Quantity & No quotation / Less / Same / More \\
\hline Expert assessments & No quotation / Less / Same / More \\
\hline Bridge & No quotation / Less / Same / More \\
\hline Engineering works & No quotation / Less / Same / More \\
\hline Nature conservation & No quotation / Less / Same / Better \\
\hline
\end{tabular}


Table 3. The action codes in newspaper items.

\begin{tabular}{|l|l}
\hline Variables & Codes \\
\hline River management & Absence / Presence \\
\hline Sanitation services & Absence / Presence \\
\hline Engineering works & Absence / Presence \\
\hline Conservation & Absence / Presence \\
\hline Water resource management & Absence / Presence \\
\hline Hazard management & Absence / Presence \\
\hline Hazards & Water shortage / Flood / Riverbank erosion / Landslide \\
\hline River maintenance or clearing & No actions / Stream bed maintenance / Riverbank \\
& maintenance \\
\hline
\end{tabular}


Table 4. The comparison of different authors in the newspapers.

\begin{tabular}{|l|l|l|}
\hline & Le Crestois & Le Journal du Diois \\
\hline Journalists & $59 \%$ & $49 \%$ \\
\hline Politicians & $17 \%$ & $24 \%$ \\
\hline Environmentalists & $5 \%$ & $1 \%$ \\
\hline Users & $5 \%$ & $6 \%$ \\
\hline Riverside residents & $5 \%$ & $2 \%$ \\
\hline Experts & $4 \%$ & $7 \%$ \\
\hline Anglers & $3 \%$ & $6 \%$ \\
\hline Farmers & $6 \%$ & $1 \%$ \\
\hline Association memberships & $0 \%$ & $5 \%$ \\
\hline Canoeists & $1 \%$ & $0 \%$ \\
\hline Hunters & $1 \%$ & $0 \%$ \\
\hline Quarrymen & $0 \%$ & $0 \%$ \\
\hline Tourists & $0 \%$ & $0 \%$ \\
\hline
\end{tabular}

